Article

\title{
Evaluation of the Water Quality and Farming Growth Benefits of an Intelligence Aquaponics System
}

\author{
Chien-Che Huang ${ }^{1}$, Hsiao-Ling Lu ${ }^{2} \oplus$, Yuan-Hsiou Chang ${ }^{3, *}$ and Tsung-Hsien Hsu ${ }^{4}$ \\ 1 Department of Leisure and Recreation Management, National Taichung University of Science and Technology, \\ Taichung 40401, Taiwan; charles0928@nutc.edu.tw \\ 2 Department of Biotechnology, National Formosa University, Yunlin 632301, Taiwan; hllu@nfu.edu.tw \\ 3 College of Intelligence, National Taichung University of Science and Technology, Taichung City 40401, Taiwan \\ 4 Department of Landscape Architecture and Environmental Planning, MingDao University, \\ Changhua 52345, Taiwan; evan@nutc.edu.tw \\ * Correspondence: f89622050@ntu.edu.tw; Tel.: +886-937523685; Fax: +886-4-22195609
}

Citation: Huang, C.-C.; Lu, H.-L.; Chang, Y.-H.; Hsu, T.-H. Evaluation of the Water Quality and Farming Growth Benefits of an Intelligence Aquaponics System. Sustainability 2021, 13, 4210. https://doi.org/ $10.3390 /$ su13084210

Academic Editor: Fernando António Leal Pacheco

Received: 26 February 2021

Accepted: 2 April 2021

Published: 9 April 2021

Publisher's Note: MDPI stays neutral with regard to jurisdictional claims in published maps and institutional affiliations.

Copyright: (C) 2021 by the authors. Licensee MDPI, Basel, Switzerland. This article is an open access article distributed under the terms and conditions of the Creative Commons Attribution (CC BY) license (https:// creativecommons.org/licenses/by/ $4.0 /)$.

\begin{abstract}
In 2019, the degree of food self-support in Taiwan was 32.08\%, which was lower than that in the previous year by $2.4 \%$. Taiwan does not have the ability to control the availability of food in the face of a food crisis. This study used an aquaponics system to implement the mutualism of fish, flowers, vegetables, and water, as well as to implement the cyclic utilization of water, so that vegetables and fruit could be produced to relieve food shortages in the world. The simulation site of this study was located on a gentle grassy slope alongside Li-tze Lake in Changhua County, Taiwan. In the simulation, three light-tight experimental buckets, with an upper rim diameter of $130 \mathrm{~cm}$, a bottom rim diameter of $125 \mathrm{~cm}$, and a height of $180 \mathrm{~cm}$, were embedded in the ground. The target vegetables and flowers were planted in pots at $17 \mathrm{~cm}$ apart, and they were planted on the water surface using the floating island principle. A solar power system enabled a motorized pump to irrigate the plants. An aerator provided adequate aeration to achieve an elementary purifying effect. The experimental results showed that, in terms of the dissolved oxygen, the mean difference of the experimental group was about $1 \mathrm{mg} / \mathrm{L}$, that of the control group was $2 \mathrm{mg} / \mathrm{L}$, and the maximum difference was $6.5 \mathrm{mg} / \mathrm{L}$. As the fish died in April, the ammonia nitrogen value of the control group was 68 times higher than that of the experimental group. Due to the nitrification in July, the ammonia nitrogen decomposed into $\mathrm{NO}_{2}$, which suddenly increased to $13 \mathrm{mg} / \mathrm{L}$ and was extremely unsuitable for the existence of aquatic organisms. This amount was five to six times higher than that of the experimental group. In terms of the fish growth rate, the control group could not bear the drastic changes in the water body at the intermediate stage, and all the fish died, whereas the fish in the experimental group were not affected. The results of this study could provide useful data for gardening, aquatic products, and space design staff.
\end{abstract}

Keywords: aquaponics; artificial floating island; water resources; food crisis; green energy

\section{Introduction}

Taiwan receives abundant rainfall; however, it covers a small territory and has a dense population, as well as steep hillsides and a non-uniform time and space rainfall distribution. The utilizable water resource per capita is $1 / 7$ th of the global average, and the stream water is polluted by factory and human discharge. The degree of food self-support in Taiwan was $32.08 \%$ in 2019 , which was $2.4 \%$ lower than that in the previous year [1]. In this study, the concept of aquaponics, combined with floating islands, could solve four problems at once, namely, it could be used to implement the mutualism of fish, flowers, vegetables, and water. Moreover, the cyclic utilization of water can also be implemented. This equilibrium system could avoid water quality deterioration, form a symbiotic relationship between fish and plants, and it could produce vegetables and fruit on its own, thereby relieving the 
world food shortage. The term "aquaponics" is a combination of "aquaculture" (fish) and "hydroponics" (the soilless culture of plants) [2].

The plants in an aquaponics system can absorb nutrients from the excrement of fish in the system and purify the water, as well as reduce the water waste and produce additional crops, but the addition of an element is needed, because fish mainly supply nitrogen [3]. In addition, the start-up period highly influences the $\mathrm{N}$ budget [4]. Aquaponics is a system that integrates recirculating aquaculture with fish-vegetable production and represents an innovative and sustainable practice [5]. A well-managed aquaponics system can increase the efficiency of nutrient retention and reduce the waste of water resources and nutritive salt discharge, which pollute the environment, while earning profits simultaneously from the two economic products of fish and vegetables [5]. It is believed that the sustainable food production of aquaponics and the cyclic utilization of the nutritive elements in water will be accepted extensively by common people in the near future [6]. The waste derived from aquaponics and aquaculture can be converted by microbes into soluble nutrients that are absorbed by plants. After these processes, the water turns into clean and safe water and flows back into the aquaculture system. The number of feeding services will influence the excretion of fish, and uneaten feed and excrement will influence the water quality [7]. A Recirculating Aquaponic System (RAS) is a water circulation system that can co-produce fish and plants and may be used to establish a superior fish culture technology that can protect good fishery conditions, provide better water quality control, reduce the wastage of water resources, and enhance sewage management and the alimentary cycle [8-12] indicated that the plants should adapt well and have a strong tolerance and absorptive capacity for pollutants. However, the RAS equilibrium and maintenance management must be designed [13]. The dissolved oxygen in water may be derived from atmospheric dissolution, natural or artificial aeration, and the photosynthesis of aquatic plants. If the water is polluted by organic matter, aquatic microorganisms will consume the dissolved oxygen in the water, while decomposing the organic material, thereby inducing lower dissolved oxygen levels in the water and even causing an oxygen deficiency [14]. Global aquaculture has grown steadily and rapidly in recent decades [15]; if it is combined with an aquaponics system, it could increase the production of multiple farming resources, and the sustainable utilization of natural resources could be achieved. RAS can increase fish growth by $2.4 \mathrm{~g}$ per day, the amount of harvested vegetables is $22 \mathrm{~kg}$, the nutritive salt in water is removed, the ammonia- $\mathrm{N}$ removal is $83 \%$, the nitrite- $\mathrm{N}$ removal is $87 \%$, the nitrate- $\mathrm{N}$ removal is $70 \%$, the total phosphorus removal is $60 \%$, the total suspended solid removal is $88 \%$, and the 5-day biochemical oxygen demand removal is $63 \%$ [16]. The combination of an aquaponics system and a recirculating system can purify the nutritive salt in the water and maintain the cleanliness of the water to help fish and vegetables grow normally, thus implementing the sustainable utilization of ecological resources.

Aquaponics can generate a nitrifier, in which $\mathrm{NH}_{4}{ }^{+}$is converted into $\mathrm{NO}_{3}{ }^{-}$by nitrification. $\mathrm{NO}_{2}{ }^{-}$conversion also occurs during the course of nitrification. Ref. [17] observed that the reduction of the $\mathrm{NH}_{4}{ }^{+}, \mathrm{NO}_{2}{ }^{-}$and $\mathrm{NO}_{3}{ }^{-}$concentrations in an aquaponics system could reduce the dissipation of $\mathrm{NO}_{2}{ }^{-}$. The vegetables that are applicable to an aquaponics system include leafy vegetables, such as Lactuca sativa, Spinacia oleracea, and Brassica chinensis Linn, as well as fruit plants, such as Solanum lycopersicum and Cucunis anguria L. [18,19]. In terms of the effect of the transmission of nitrogen in water on Lycopersicon esculentum and Brassica campestris L. subsp. chinensis planted in an aquaponics system, the Lycopersicon esculentum has a larger root surface area than Brassica campestris L. subsp. chinensis, and therefore it has abundant symbiotic nitrobacteria and can treat the nitrogen matter in water effectively [20]. Another advantage of aquaponics is that nitrogen is an element that is necessary for the growth of all organisms. Fish feed, which contains a high protein level, is the main source of nitrogen in fish culture and accounts for $50-70 \%$ of the fish production cost [21]. In comparison to general aquaculture systems, where only $25 \%$ of the nitrogen is absorbed by fish and about $70 \%$ of the ammonia is discharged into the environment, the nutrition transmission benefit of aquaponics has been observed [22]. 
In terms of ecological conservation, the [23] indicated that when a floating island is isolated from the land, flying insects, spiders, fish and amphibians preying on insects, as well as birds preying on amphibians and fish, come, in turn, to form a small floating island of a food chain ecosystem. Artificial floating islands have the following advantages: they are exempt from land costs and can save land area; the plant root systems suspended in water physically remove the suspended solids in the water; contaminants are absorbed and used by biosynthesis; and a bio-membrane adhesion medium is provided [24-26]. Besides the abovementioned functions, an artificial floating island provides organisms with a habitat and conservation, increases the biological habitats in the water, and provides a safe place for diversified organisms, such as birds, fish, insects, and amphibians. Artificial floating islands have been used successfully to restore birds in Canada $[27,28]$.

The purpose of this research is to build an artificial floating island that can grow vegetables and flowers on water. In addition, the floating island will preserve its main function of purifying the water and increasing the biodiversity. Based on the concept of sustainable agriculture, our research and design of floating islands will provide a potential solution for circular agriculture in Taiwan.

\section{Materials and Methods}

\subsection{Materials}

The experimental site was located on a gentle grassy slope alongside Li-tze Lake, located at the MingDao University in the Changhua County, Taiwan. The three buckets used in this study were light-tight plastic buckets with an opening diameter of $150 \mathrm{~cm}$, a bottom diameter of $145 \mathrm{~cm}$, and a height of $175 \mathrm{~cm}$. The three buckets of water were taken from Li-tze Lake, the water source of Li-tze Lake, and the domestic sewage discharged from the students' dormitory to the lake. An artificial floating island was built in the bucket, and the plants were arranged on a floating island. One bucket did not have a floating island and was used as the control. The other two buckets were each provided with an artificial floating island. The two buckets of water were used for planting edible vegetables and ornamental flowers, respectively, as shown in Figure 1a.

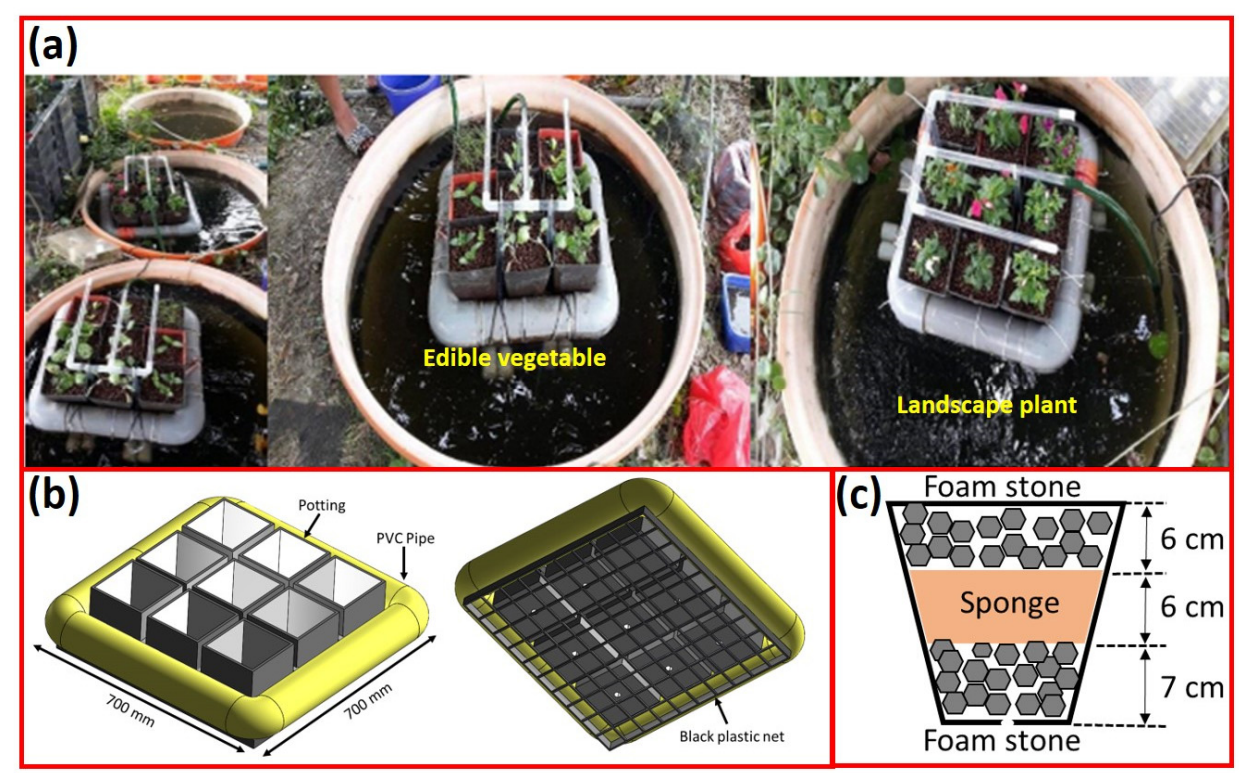

Figure 1. (a) Actual set-up diagram of the aquaponics system; (b) schematic diagram of the artificial floating island; and (c) schematic diagram of the foam stone and sponge filling in the pot.

As shown in Figure $1 \mathrm{~b}$, each artificial floating island was a square floating island with a $700 \times 700 \mathrm{~mm}$ outer frame made of 4 " PVC pipes. Square pots were placed on the floating island. The size of each pot was $220 \times 220 \times 170 \mathrm{~mm}$, and the pots were arranged in a $3 \times 3$ array. A round hole, with a radius of $20 \mathrm{~mm}$, was drilled into the bottom of each 
pot. The bottom of the artificial floating island was provided with a $650 \times 650 \mathrm{~mm}$ black plastic net to prevent the pots from dropping off. A submerged motor was placed in the bucket to pump the water, which flowed equally through the pipe branches into the nine pots. The fish excrement generated ammonia, and the ammonia was converted into nitrite and nitrate for the plant roots to absorb. The roots of the plants purified the water, while absorbing nutrients, and the clean water flowed back to the fish pond.

A $7 \mathrm{~cm}$ thick foam stone was placed in the bottom of each pot on the artificial floating island and then a $6 \mathrm{~cm}$ thick sponge was placed on it, so that the water could be retained in this layer for the plants; meanwhile, the impurities were filtered, in order to purify the water. Finally, a $6 \mathrm{~cm}$ thick foam stone was loaded for fixing the plants, as shown in Figure 1c.

A bubble generator was placed in the bottom of the buckets of the control group, the flower group and the vegetable group, respectively, for aeration and to increase the dissolved oxygen in water, to the avoid unpleasant odors and to provide sufficient oxygen for the fish. The buckets were filled with water, the artificial floating islands and motor equipment were installed, and the fish school was put into the water. When all the materials had settled down in water and the fish schools were stable after $24 \mathrm{~h}$, the experiment began.

\subsubsection{Flower and Vegetable Planting and Fish Selection of an AQUAPONICS System}

This study cultured a fish school in a bucket and grew plants on a floating island to simulate an aquaponics system. One of the three buckets was the control group and did not have a floating island. Five kinds of vegetables and five kinds of flowers were planted on the floating islands in the other two buckets, respectively.

Daily food vegetables were planted in the $3 \times 3$ floating island pots on one floating island, including Brassica juncea, Chrysanthemum coronarium, Brassica oleracea var. capitata, Allium fistulosum, and Lactuca sativa (two plants per species).

The flowers planted in the $3 \times 3$ floating island pots on the other floating island included Catharanthus roseus, Zinnia angustifolia, Cuphea hyssopifolia, Gomphrena globosa and Begonia grandis (two plants per species).

A total of 20 common and edible fish from the Carassius auratus and Oreochromis mossambicus species were cultured in each bucket of water.

\subsubsection{Solar-Powered Equipment}

The pump used for plant irrigation and the motor used for aeration were powered by solar energy equipment. The solar panel was comprised of two $1600 \times 1080 \mathrm{~mm}, 100 \mathrm{~W}$ monocrystalline solar panels, and it was tilted at $23^{\circ}$ and oriented south, to coordinate with the lighting direction at the experimental site. A control box and two deep-cycle EVX solar batteries $(12 \mathrm{~V}, 100 \mathrm{~A})$ were placed under the solar panel.

\subsection{Methods}

The measurements and observations of this study lasted for one year, and the test period was between 1 November 2018 and 1 October 2019. The water quality and ecological and plant growth index values were recorded. The measured physical environment data were comprehensively analyzed with the water quality fluctuation and shrub and vegetable plant growth indices, to provide a reference for studying the benefit of aquaponics systems and in order to make the subsequent corrections. The water quality was measured using a YSI-Pro Plus multi-parameter water quality analyzer and a DR/890 portable multiparameter colorimeter. The YSI-Pro Plus water quality monitoring data were collected at a fixed time once per week, namely, between 12:00 and 18:00 every Friday. The DR/890 portable multi-parameter colorimeter tested the water quality once per week.

\subsubsection{Water Quality Monitoring}

The water quality was tested by using a YSI-Pro Plus multi-parameter water quality analyzer. The test items included the water temperature, $\mathrm{pH}$ value, Dissolved Oxygen 
(DO), Electrical Conductivity (EC), and Oxidation-Reduction Potential (ORP). The water quality data of each water sample will simultaneously display the above five data on the panel of the YSI-Pro Plus multi-parameter water quality meter. The experimental procedure will be repeated five times to obtain the average value before the data are completed. Water samples were taken at $5 \mathrm{~cm}$ and $85 \mathrm{~cm}$ below the surface and tested once per week, between 12:00 and 18:00 every Friday.

The changes in the Total Nitrogen (TN), Total Phosphorus (TP), Ammonia Nitrogen $\left(\mathrm{NH}_{3}-\mathrm{N}\right)$, nitrite $\left(\mathrm{NO}_{2}\right)$ and nitrate $\left(\mathrm{NO}_{3}-\mathrm{N}\right)$ contents were tested by using a $\mathrm{HACH} \mathrm{DR} / 890$ portable multi-parameter colorimeter. The water samples taken at $85 \mathrm{~cm}$ below the surface were sampled and tested once per month.

\subsubsection{Fish Growth Detection Method}

Five individuals of the Oreochromis mossambicus and Carassius auratus species were taken out of each bucket per week. The body weights of the two fish species were measured and recorded, and the body lengths were measured, using vernier calipers. The body length, also known as the standard length, is a straight length, from the snout to the tail fin base, i.e., the overall length minus the length of the tail fin.

\subsubsection{Plant Growth Monitoring}

The outline dimensions of the plants were evaluated according to the common growth index, expressed as Equation (1) [29-31]:

$$
\text { Growth index }=(L+W+H) / 3
$$

where:

$L=$ Maximum length of the crown $(\mathrm{CM})$

$W=$ Maximum width of the crown $(\mathrm{CM})$

$H=$ Maximum height of the crown $(\mathrm{CM})$.

The plant growth was measured between November 2018 and October 2019, and the maximum length, width, and height (unit: millimeter) of each plant were measured using vernier calipers every week during the test. According to [31], the sum of the length, width, and height can be divided by 3 to obtain the growth index of a plant.

\section{Results and Discussion}

\subsection{Aquaponics System-Fish Schools and Plant Growth}

In terms of plant growth, the growth of the vegetable group was influenced by insects and always fluctuated. The Allium fistulosum was not eaten by insects due to its bitter taste, and it grew continuously. As there were fewer insects after replanting during AprilMay 2019, favorable growth was gradually restored. The vegetables were intolerant of wind, and due to the typhoon season in June, the Allium fistulosum, Lactuca sativa, Brassica oleracea, and Chrysanthemum coronarium died, which caused the growth rate to become zero. However, there was significant growth after another replanting. In particular, the growth rate of Chrysanthemum cornarium was 0 on June 4 , and it increased to $58.24 \mathrm{~cm}$ on 28 October. Compared to the growth rate of Brassica juncea, Allium fistulosum, Lactuca sativa, and Brassica oleracea, which was $51.63 \%, 8.82 \%$, and $8.61 \%$, respectively, the growth rate of Chrysanthemum cornarium was only $55.15 \%$.

The growth of the flower group was restricted by the blooming period and the size of the experimental pots. The growth of the Begonia grandis worsened due to the high air temperature from July to October. The Cuphea hyssopifolia had the best growth in the flower group; however, its leaves and petals withered and dropped off, due to the high humidity, and its growth rate decreased. When the air temperature dropped in the midand late-stages, the growth was restored. In the flower group, Cuphea hyssopifolia had the best growth status on 28 April, which was better than that of Begonia grandis at $14.6 \mathrm{~cm}$, 
Catharanthus roseus at $22.6 \mathrm{~cm}$, and Zinnia angustifolia at $22.8 \mathrm{~cm}$, while Gomphrena globose had the worst performance, at only $27.5 \mathrm{~cm}$.

According to the experimental results, the Control group Carassius auratus all died on 15 November, but the control group Oreochromis mossambicus only died on 16 June, with a growth rate of $12 \%$. In the Oreochromis mossambicus group, the flower group had the longest body length at $17 \mathrm{~cm}$ on October 16 , which was $6 \%$ higher than the vegetable group. In the Carassius auratus, the flower group had a final body length of $10 \mathrm{~cm}$, which was $7 \%$ higher than the vegetable group. It can be seen that the environmental growth conditions of the flower group were better, and it is speculated that the water quality conditions may be affected by the roots of the plant species. The fish in the experimental group of the aquaponics system had stable growth. The growth index of the Oreochromis mossambicus in the vegetable group and the flower group was doubled. The Oreochromis mossambicus could grow continuously, but because of the habitat limitations, after it grew to a certain size, it did not continue growing. In the control group, which was free of artificial floating islands, all of the Carassius auratus died in the first month. The main water source was from the campus sewage. The fish school in the control group excreted continuously; the water could not be purified without the artificial floating island and plants, and the water quality deteriorated continuously, due to the fish excretion and uneaten feed. The Carassius auratus and Oreochromis mossambicus were all vigorous, but the Carassius auratus had higher environmental requirements than the Oreochromis mossambicus, therefore the Carassius auratus all died in the first month. The Oreochromis mossambicus grew the fastest because the control group had the most total phosphorus. In this environment, water moss was likely to grow, which provided sufficient food for the Oreochromis mossambicus. However, in the mid-and late- stages, the algae died, due to algae bloom, the amounts of ammonia nitrogen waste and nitrite increased, and the dissolved oxygen decreased, causing all the fish to die, as shown in Figure 2. In the water with artificial floating islands, the plants could absorb the excessive nutrients and impurities in the water, the dissolved oxygen in the water was maintained, and the redox reaction was enhanced to implement water purification.

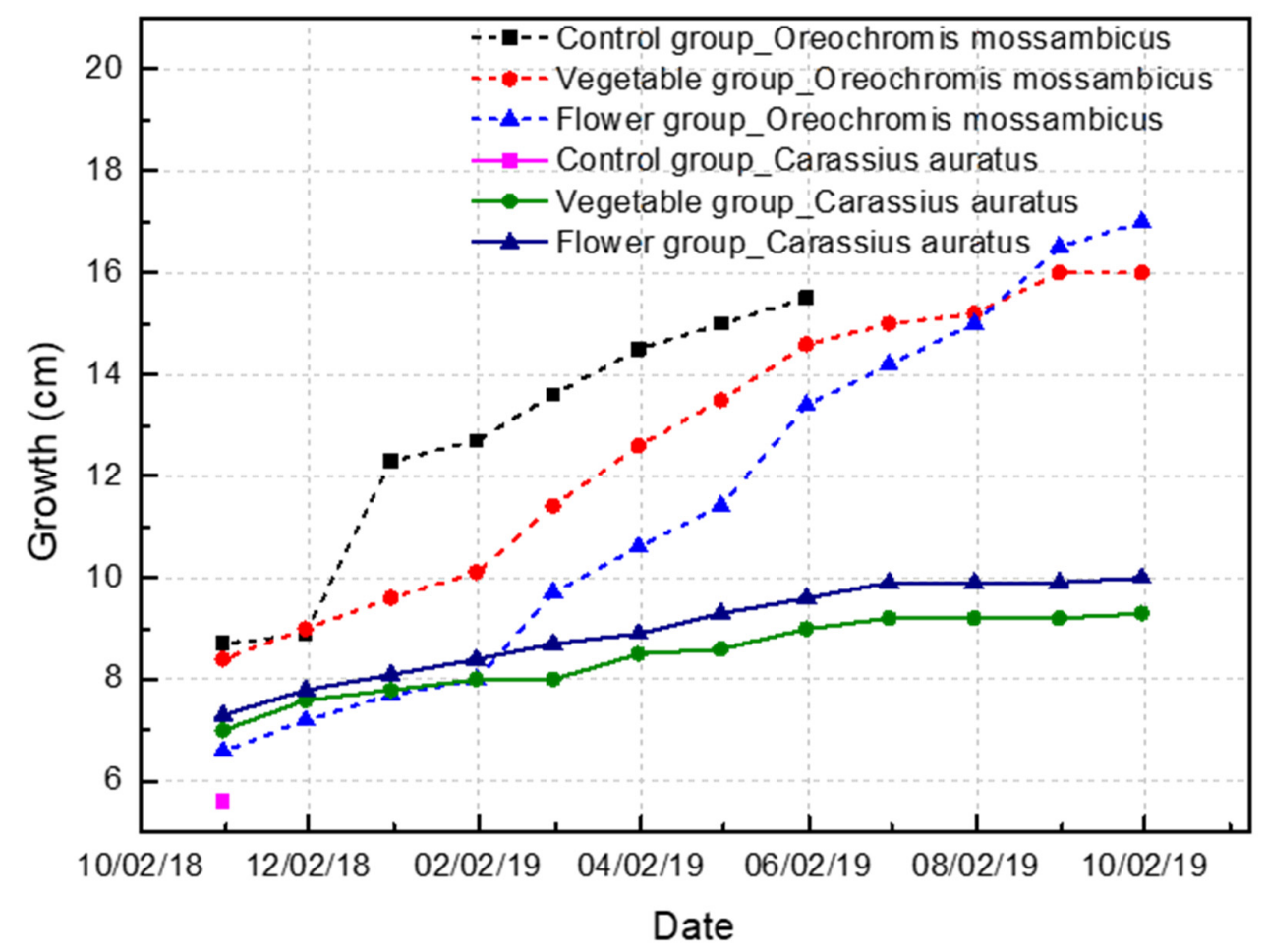

Figure 2. Changes in the growth of Oreochromis mossambicus and Carassius auratus in the water bodies of the control, vegetable, and flower groups. 


\subsection{Analysis of Water Quality Fluctuation of the Aquaponics System}

\subsubsection{Water Temperature and Dissolved Oxygen}

The water temperature of the control group, the vegetable group and the flower group varied with the seasons, but the three groups had coincidental trends. The vegetable group had the highest average water temperature, at $24.8^{\circ} \mathrm{C}$, while the flower group had the lowest average water temperature, at $24.5^{\circ} \mathrm{C}$. The average temperature of the water in the control group was $24.8^{\circ} \mathrm{C}$, as shown in Figure 3a. The control group, which was free of floating islands, had water temperatures that were higher or lower than the water temperatures of the vegetable and flower groups, because the water was unshielded and directly influenced by the ambient environment.
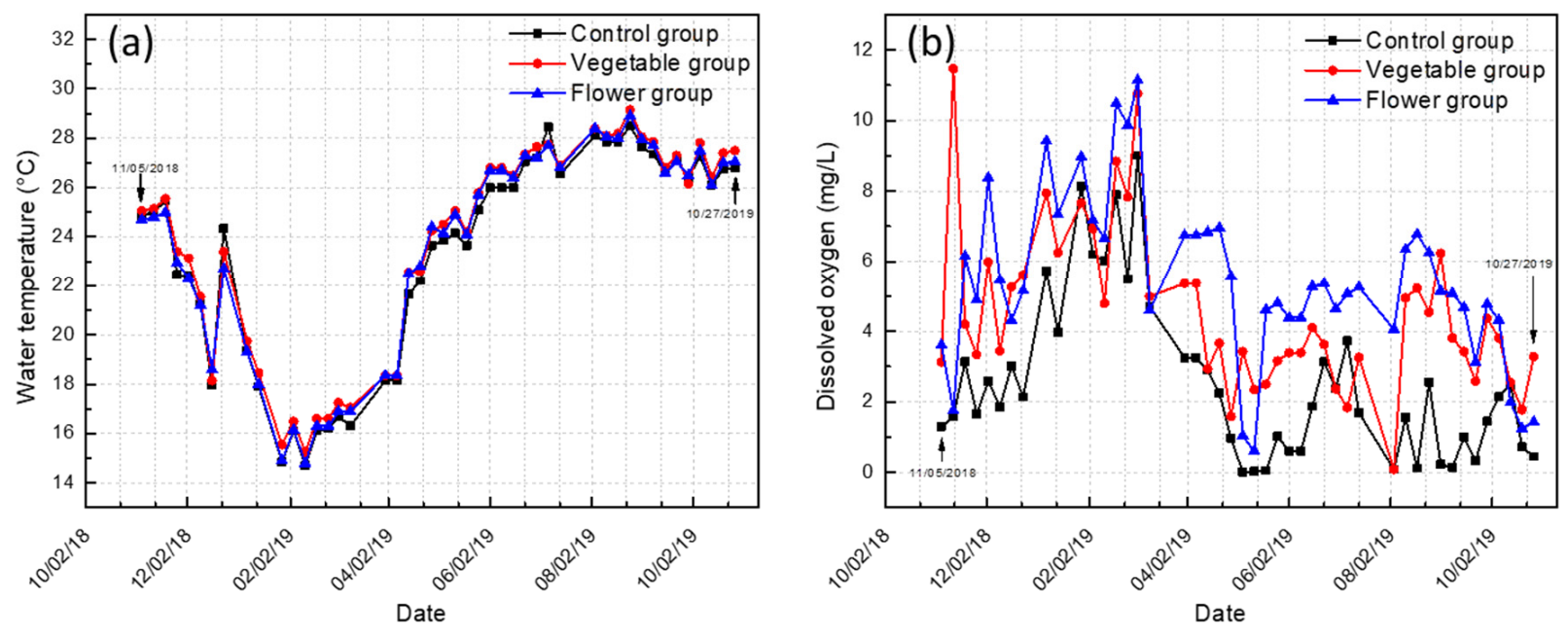

Figure 3. Annual changes in the water bodies of the control, vegetable, and flower groups: (a) water temperature; and (b) dissolved oxygen.

The dissolved oxygen in the water was influenced by the temperature and the contents in the water. Bubble generators were placed in the control, flower, and vegetable groups to increase the oxygen content in the water and to allow the influential conditions to be coincidental. As shown in Figure 3a, the three groups had similar trend variations for the dissolved oxygen in the water, and these trends were influenced by the temperature. The higher the ambient temperature, the higher the water temperature would be, and the lower the dissolved oxygen in the water. In contrast, the dissolved oxygen increased as the temperature fell, as shown in Figure 3a.

The year-round average dissolved oxygen level in the vegetable and flower groups was $4 \sim 8 \mathrm{mg} / \mathrm{L}$. The dissolved oxygen of the vegetable and control groups measured on one day could have a difference as large as 18 times. Among them, the DO of the flower group reached $6.69 \mathrm{mg} / \mathrm{L}$ on 25 August, which was $23 \%$ higher than that of the vegetable group, while the control group was only $0.05 \mathrm{mg} / \mathrm{L}$. It can be seen that an Intelligence Aquaponics System has the function of aeration and can stabilize the DO in the water, which is helpful because it grows in aquatic organisms. In the mid-stage of the experiment, the dissolved oxygen level of the control group fluctuated due to eutrophication, and the excessive growth of algae induced the fluctuation of the dissolved oxygen level. The leaves of the vegetable and flower groups fell in spring and the flowers and fruit sank to the bottom, causing the dissolved oxygen level to decrease. It recovered to $2 \sim 6 \mathrm{mg} / \mathrm{L}$ after the aquaponics system was set up and became five or six times that of the control group. In the mid- and late-stages, the dissolved oxygen at the bottom of control group remained at $0 \sim 1 \mathrm{mg} / \mathrm{L}$. Because the fish school died, the amount of organic matter and the number of aquatic microorganisms increased, causing the dissolved oxygen in the water to be consumed and to remain at a low value. 


\subsubsection{ORP \& EC}

Natural microbes can purify the various organics and inorganics in sewage by a redox reaction. The cleanliness of a water sample can be obtained from the ORP, and the oxidation-reduction power of a water body can be known.

The higher the ORP value of a water sample is, the higher the amount of dissolved oxygen in the water. A high level of dissolved oxygen in water can promote microbes and bacteria to decompose dead tissue and pollutants effectively. Generally, the higher the ORP value is, the stronger the capacity of decomposition in the water body, which means that the water body is healthier. Figure 4a shows that the annual average ORP of the vegetable group in the water with an artificial floating island was $85.5 \mathrm{mV}$ and the annual average ORP of the flower group was $100 \mathrm{mV}$. When the vegetables or flowers were planted on the floating island, the ORP remained positive and the dissolved oxygen in the water could be increased effectively. The redox reaction of the water was enhanced, and the domestic sewage from the campus lake, the fish school excrement, and the uneaten feed could be decomposed effectively.
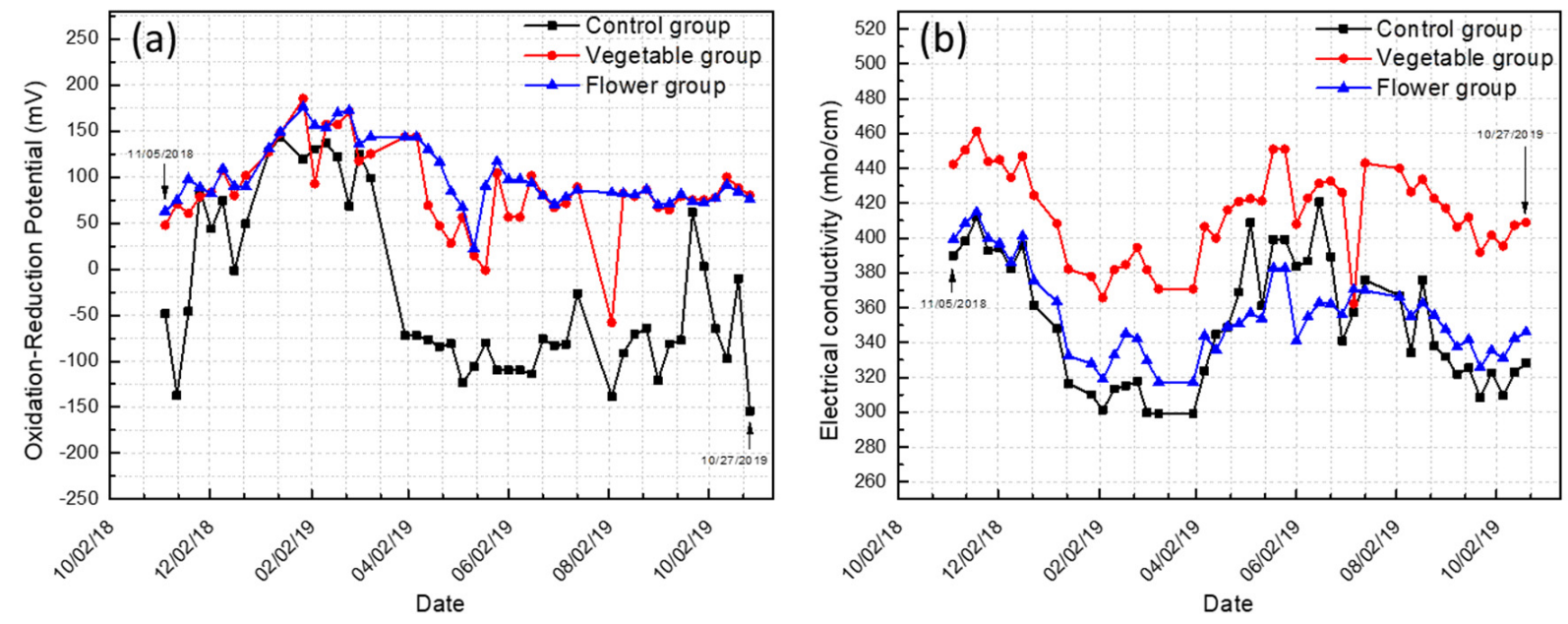

Figure 4. Changes in the water bodies of the control, vegetable, and flower groups: (a) Oxidation-Reduction Potential ORP; and (b) EC.

On 27 October, the ORP of the control group reached the lowest point of $-173.9 \mathrm{mv}$, while the values of the vegetable and flower groups were $77.4 \mathrm{mv}$ and $76 \mathrm{mv}$, respectively, which is quite close, with only a $1.9 \%$ difference. It can be seen that an Intelligence Aquaponics System has a stable function for the ORP. Under the same test conditions, the planting of flowers on the artificial floating island was more effective in purifying the water than the planting of vegetables, so that the water quality is maintained within a certain range in order for organisms to live, and the ORP is relatively stable (Figure 4a).

The water in the control group (without an artificial floating island) was taken from the domestic sewage in the campus lake. The contaminants in the water, namely the Carassius auratus, which all died in the first month, the uneaten feed and the fish school excrement were all deposited on the water bottom. Bacteria and microbes decomposed the organics in the deposits and consumed a large amount of oxygen, thus causing the dissolved oxygen in the water to decrease. There were no plants in the water, therefore the redox reaction could not be performed effectively to purify the water. The ORP was negative, and the annual average was $-28.1 \mathrm{mV}$. The negative ORP indicated that the water in the control group was quite dirty, making it unsuitable for the growth of organisms and plants.

The redox corresponds to the EC, and the higher the EC, the lower the ORP. The $\mathrm{EC}$ has a considerable influence on plant irrigation. The EC is related to the total ionic concentration in water, as well as to the mobility, valence number, relative concentration and water temperature. Most salts can be ionized, therefore a higher salt content represents 
a lower fitness for irrigation. The EC is less than $750 \mathrm{mho} / \mathrm{cm}$ for the irrigation water quality in Taiwan. Among the final values of EC on October 27, the vegetable group performed best at $410 \mathrm{mho} / \mathrm{cm}$, followed by the flower group at $346.2 \mathrm{mho} / \mathrm{cm}$, and the control group performed the worst at only $328.1 \mathrm{mho} / \mathrm{cm}$, and the difference between the vegetable and flower groups was about $16.6 \%$, which is speculated to be caused by fish disturbing the suspended particles in the water (Figure $4 b$ ).

The EC of the vegetable and flower groups was 300 to 470, which was suitable for plant irrigation. The EC of the control group was quite close to that of the flower group at the beginning; however, in the mid- and late-stages, as the control group did not have any equipment installed and there were no fish to disturb the water, so the suspended particles in the water settled to the bottom. The difference between the EC values at $5 \mathrm{~cm}$ and $85 \mathrm{~cm}$ below the surface was more than twice as much in May. The bottom salinity was relatively high and unstable. The upper and lower layers of the water in the vegetable and flower groups showed convection and there was no difference in the EC. It remained within a stable range and tended to decrease, which meant that the artificial floating island with plants in the water could absorb the nutritive salt in the water and maintain the water stability.

There is little difference in the EC between the upper and lower water layers of the two groups of vegetables and flowers, but the values of the control group are quite different. It can be seen that the Intelligence Aquaponics System has a certain effect. Taking EC on 12 May as an example, the upper and lower water layers of the vegetable group were $423 \mathrm{mho} / \mathrm{cm}$ and $422.2 \mathrm{mho} / \mathrm{cm}$, which differed by only $0.2 \%$, while the upper and lower water layers of the flower group were $356.6 \mathrm{mho} / \mathrm{cm}$ and $356.9 \mathrm{mho} / \mathrm{cm}$, respectively, with a difference of only $0.1 \%$, and the upper and lower water layers of the control group were $299.7 \mathrm{mho} / \mathrm{cm}$ and $518 \mathrm{mho} / \mathrm{cm}$, which differed by as much as $42 \%$. It can be seen that the EC of the upper and lower water layers of the control group is unstable and different. It is speculated that the climate turns hot in May, and the growth of algae in the water will affect the water quality, as shown in Figure 5.

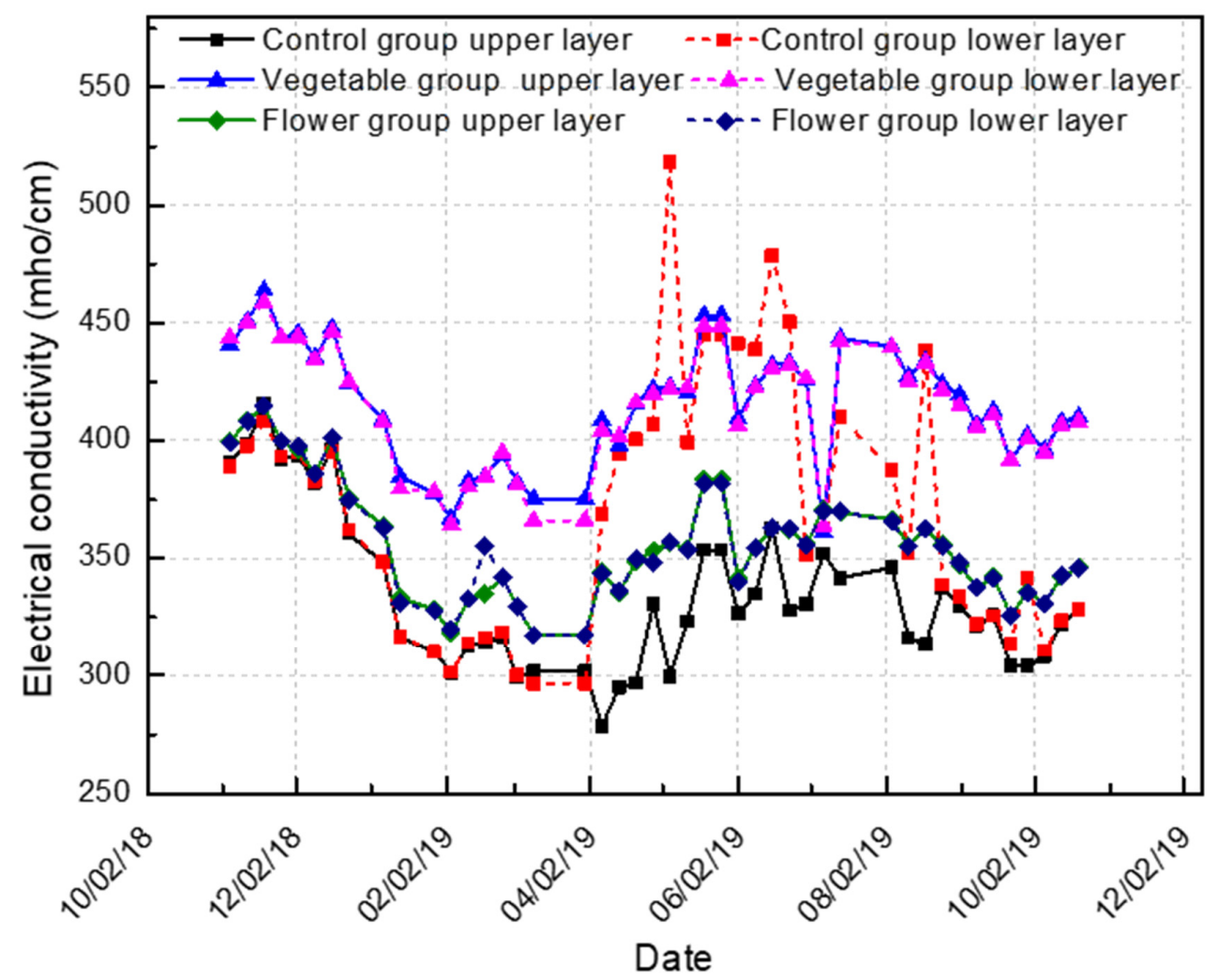

Figure 5. EC variation in the different water layers of the control, vegetable, and flower groups. 


\subsubsection{Total Phosphorus in the Water Body}

The water used in the control, vegetable, and flower groups came from the campus lake of the MingDao University and consisted of wastewater from daily life. The most familiar daily non-fecal drainage is the water used for cleaning, which often contains cleansers, therefore the acid and soda concentrations and total phosphorus content in the water were measured. The total phosphorus content was measured because cleansers are usually mixed with phosphate compounds to enhance the cleaning effect.

The factors influencing the $\mathrm{pH}$ of the water included the $\mathrm{NO}_{2}$ exhaled from the fish, the leftover feed, excrement, plants in the water body, and the ambient fallen leaves and fruits in the water, which released tannic acid and changed the $\mathrm{pH}$ value of water; therefore, the fallen leaves and fruits in the water needed to be removed periodically.

The water bodies used in this study were taken from the water outlet of Li-tze Lake in November 2018. In the beginning, the $\mathrm{pH}$ value of the three water bodies was about $\mathrm{PH}$ 6.5, indicating that the water was neutral. The $\mathrm{pH}$ value changed steadily within a range of $\mathrm{PH} 6 \sim 8$ during the research process. However, the $\mathrm{pH}$ value of the control group fluctuated largely in the mid-stage as the fish died and, as there was no fish disturbance in the late-stage, the $\mathrm{pH}$ of the upper layer became quite different from that of the bottom layer. The $\mathrm{pH}$ value of the water bodies of the vegetables and flowers changed steadily, in comparison to the water body of the control group without plants, as shown in Figure 6a, as there was circulation inside the water bodies, and the $\mathrm{pH}$ differences between the upper and lower water layers were small.
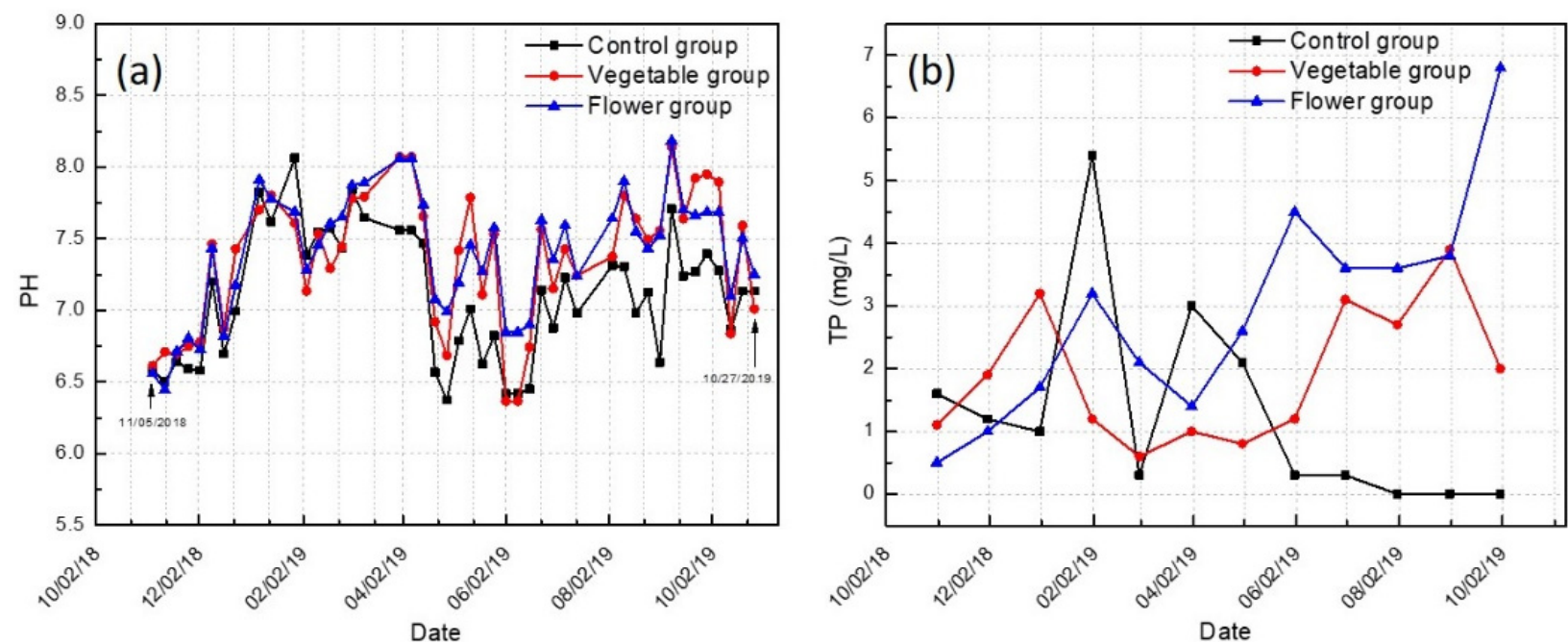

Figure 6. Changes in the water bodies of the control, vegetable and flower groups: (a) pH value; and (b) total phosphorus.

The total phosphorus is measured by measuring the amount of orthophosphate, compound phosphate and organophosphorus in the water. The phosphor in sewage generally exists as orthophosphate and compound phosphate. If the total phosphorus concentration in a water sample is high, the water may be polluted by industrial wastewater, domestic sewage, cleansers or fertilizers. Phosphor is an important nutrient for plant growth; however, when excessive phosphor enters a water body, the algae will reproduce and die in large quantities. Their decomposition consumes a large amount of oxygen and causes the dissolved oxygen in water to be exhausted, thus forming eutrophication. However, phosphor can promote the differentiation of flower buds and budding, making the flowers colorful, vigorous and plump, and it can promote plant growth. The application of phosphor in the late stage of plant growth and development is the most effective.

The total phosphorus of the control group was high in February. The dissolved oxygen in the water rose suddenly and an algae bloom occurred, but in March, a lot of the algae died and the dissolved oxygen dropped suddenly, as shown in Figure 6b. On 2 October, the $\mathrm{TP}$ of the flower group reached $6.8 \mathrm{mg} / \mathrm{L}$, while that in the vegetable group also reached 
$2 \mathrm{mg} / \mathrm{L}$, and the control group had almost no TP. It is speculated that the decayed leaves of the flower and vegetable groups increased the TP, after the dead algae decomposed, the amount of phosphor in the control group increased; however, in June, duckweed began growing in large quantities in the upper layer. The duckweed absorbed the phosphor and caused the total phosphorus to decrease to $0 \sim 0.3$, as shown in Figure $6 \mathrm{~b}$.

The total phosphorus content of the vegetable and flower groups increased continuously from November 2018 to March 2019, but there was no sudden rise, compared to the total phosphorus content of the control group. The vegetables and flowers grew obviously during this period. Phosphor is quite important for the primary growth of vegetable plant seedlings, and insufficient phosphor will influence a differentiation in the growth. The total phosphorus content in the water body of the vegetable group was lower than that in the flower group. The plants of the vegetable group were replanted after a typhoon occurred in June. It could be observed in Figure 7 that the growth rate of the plants in the vegetable group that were replanted after the typhoon, was higher than that before the typhoon, and the total phosphorus content was lower than that in the water of the flower group. The planting of either flowers or vegetables in the water could effectively reduce the total phosphorus content in the water and reduce the mass breeding of algae.
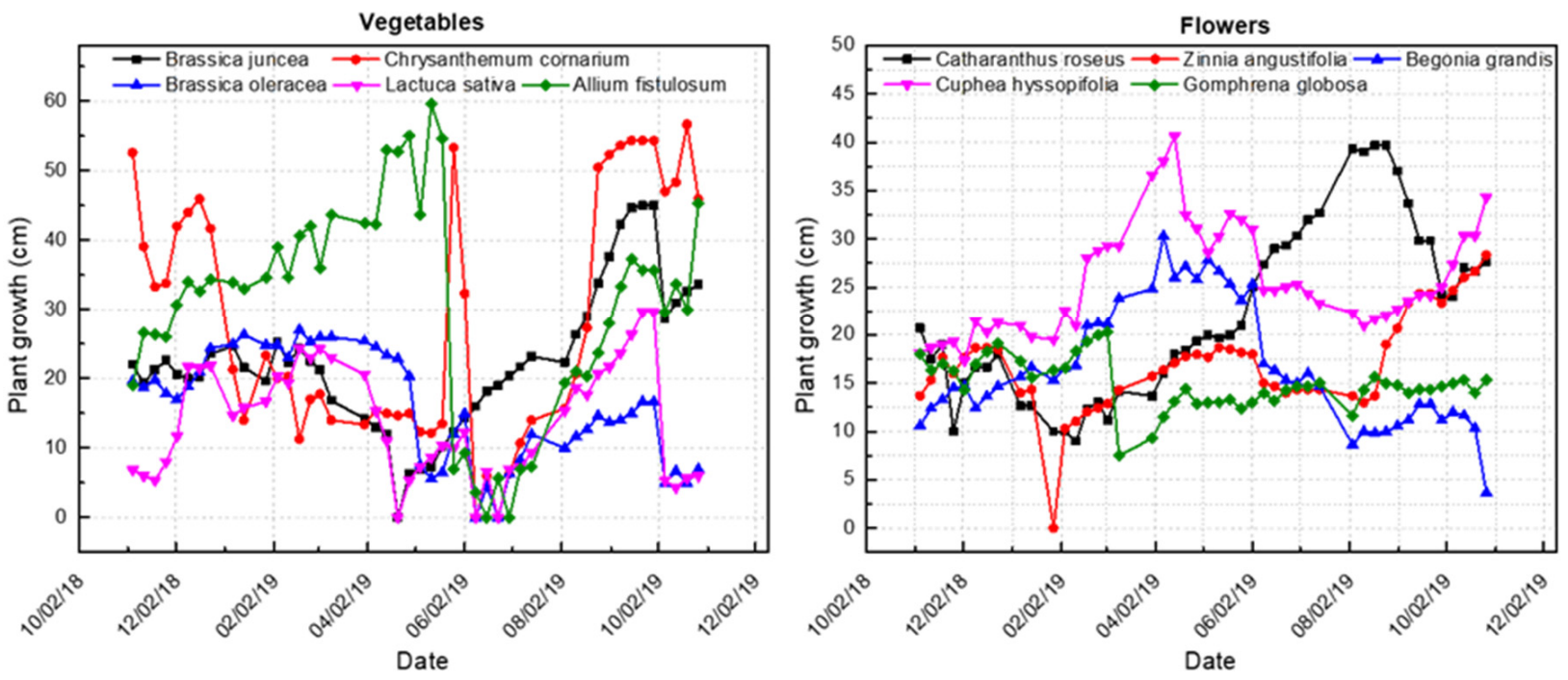

Figure 7. Growth trends of vegetables and flowers in the aquaponics system.

\subsubsection{Analysis of Nitrogenous Substances in the Water Body}

Nitrogen is the most abundant element in the atmosphere and it is an essential element of all organisms. Nitrogen fertilizer is used in large quantities in the crop growing process, as it promotes plant growth. However, nitrogenous fertilizer flows into rivers and lakes as runoff and contaminates the water. The nitrate and nitrite in water are requisites for the growth of plankton in water. When the nitrogen content in water is high, the water becomes eutrophicated, inducing the mass mortality of fish.

The total nitrogen content in water is an important index for measuring water quality and contributes to the evaluation of the pollution level and cleanliness of a water body. The total nitrogen is the total amount of different forms of inorganic nitrogen and organic nitrogen. Inorganic nitrogen includes $\mathrm{NH}_{3}-\mathrm{N}, \mathrm{NO}_{2}-\mathrm{N}$, and $\mathrm{NO}_{3}-\mathrm{N}$. In this part of the study, the water quality was analyzed according to the $\mathrm{NH}_{3}-\mathrm{N}, \mathrm{NO}_{2}-\mathrm{N}$, and $\mathrm{NO}_{3}-\mathrm{N}$ in the water body.

The nitrogen content in water is one of the primary indicators of eutrophication. It was found that the total nitrogen rose sharply due to the mass mortality of fish during the mid-stage, and that the total nitrogen index was less than the standard $12 \mathrm{mg} / \mathrm{L}$ of the daily emissions from public sewers. Only the total nitrogen of the control group increased to almost $12 \mathrm{mg} / \mathrm{L}$ in April, at which time the fish in the control group died. In comparison 
to the experimental group, the total amount of nitrogen in the two groups was lower than $10 \mathrm{mg} / \mathrm{L}$; however, that of the flower group increased during this period, due to the petals and leaves falling into the water. Taking 2 April as an example, the TN of the flower group was $2 \mathrm{mg} / \mathrm{L}$, that of the vegetable group was $0 \mathrm{mg} / \mathrm{L}$, and that of the control group was $12.9 \mathrm{mg} / \mathrm{L}$; the difference was 6.5 times. The death of fish and algae in the control group was the main cause of the increase in TN, as shown in Figure 8a.
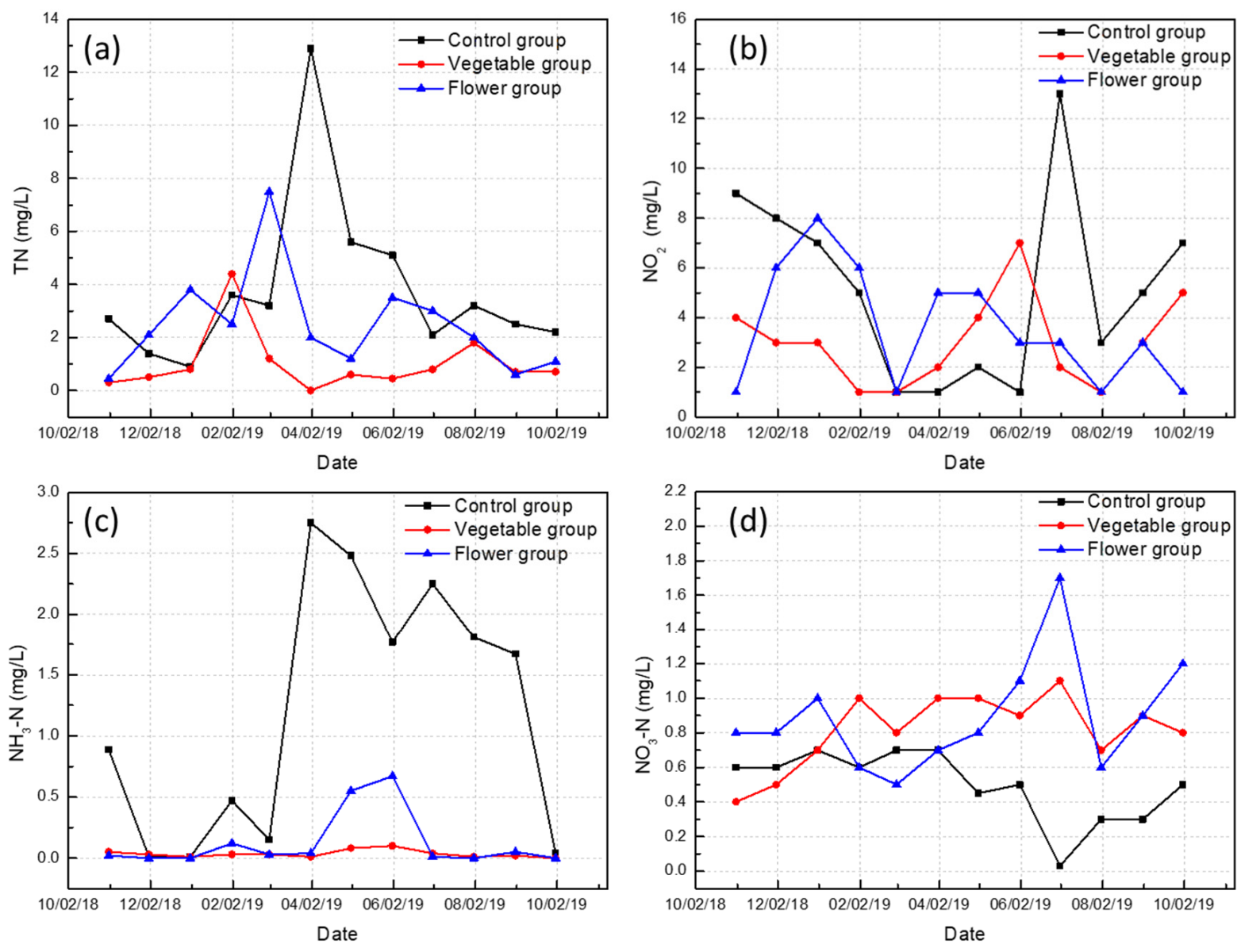

Figure 8. Changes in the water bodies of the control, vegetable, and flower groups: (a) total nitrogen; (b) $\mathrm{NO}_{2}-\mathrm{N}$; (c) $\mathrm{NH}_{3}-\mathrm{N}$; and (d) $\mathrm{NO}_{3}-\mathrm{N}$.

The $\mathrm{NO}_{2}-\mathrm{N}$ level decreased to $1 \mathrm{mg} / \mathrm{L}$ in March and increased to $13 \mathrm{mg} / \mathrm{L}$ in July, after which it decreased greatly. The $\mathrm{NO}_{3}-\mathrm{N}$ level decreased to $0.03 \mathrm{mg} / \mathrm{L}$ in July. The nitrogenous substances of the control group fluctuated greatly, possibly because the dissolved oxygen in the water of control group decreased greatly in March. Taking 2 July as an example, the $\mathrm{NO}_{2}$ of the flower group was $3 \mathrm{mg} / \mathrm{L}$, that of the vegetable group was $2 \mathrm{mg} / \mathrm{L}$, that of the control group was $13 \mathrm{mg} / \mathrm{L}$; the difference was 6.5 times, as shown in Figure 3b. When water is deficient in oxygen, anaerobic ammoxidation occurs. Nitric acid is converted into nitrous acid by bacteria and microbes, and then into NO, which is combined with oxygen into $\mathrm{NO}_{2}$ or $\mathrm{N}_{2}$, and then it diffuses into the atmosphere. As shown in Figure $8 b, \mathrm{~d}$ the $\mathrm{NO}_{3}-\mathrm{N}$ decreased and the $\mathrm{NO}_{2}-\mathrm{N}$ increased. On the other hand, $\mathrm{NH}_{3}-\mathrm{N}$ and nitrous acid exist simultaneously and turn into $\mathrm{N}_{2}$ and water in an oxygen-deficient state. The equation is $\mathrm{NH}_{4}{ }^{+}+\mathrm{NO}_{2}{ }^{-}=\mathrm{N}_{2}+\mathrm{H}_{2} \mathrm{O}$. The amount of dissolved oxygen in the water decreased greatly in July, as shown in Figure $8 \mathrm{~b}$. The $\mathrm{NH}_{3}-\mathrm{N}$ and nitrous acid levels also decreased greatly, as shown in Figure 8c,d. The water of the control group only contained fish and the amount of nitrogenous substances in the water fluctuated greatly; therefore, the water was susceptible to anaerobic ammoxidation. Another reason for the reduction of $\mathrm{NH}_{3}-\mathrm{N}$ is that duckweed often grew in large quantities on the water's surface, which helped to absorb the $\mathrm{NH}_{3}-\mathrm{N}$ waste and reduce the $\mathrm{NH}_{3}-\mathrm{N}$ content. 
The water bodies of the flower group and the vegetable group were steadier than the water body of the control group. The oxygen content in the water was sufficient, the nitrogen substances could perform nitrification to convert $\mathrm{NH}_{3}-\mathrm{N}$ into nitrous acid and could then nitrify it into nitric acid, through an aerobic reaction, which eventually became $\mathrm{N}_{2}$ and was released to the atmosphere. The nitrogen substances absorbed by the plants were mostly $\mathrm{NH}_{3}-\mathrm{N}$ and $\mathrm{NO}_{3}-\mathrm{N}$, therefore the plants in the water body contributed to the stabilization of the $\mathrm{NH}_{3}-\mathrm{N}$ and $\mathrm{NO}_{3}-\mathrm{N}$, compared to the water body of the control group.

The $\mathrm{NO}_{2}-\mathrm{N}$ in the water body of the control group suddenly increased to $13 \mathrm{mg} / \mathrm{L}$ in July, causing the fish to die in quick succession. The $\mathrm{NO}_{2}-\mathrm{N}$ of the vegetable and flower groups fluctuated; however, the concentration of $\mathrm{NO}_{2}-\mathrm{N}$ for killing fish is $10 \sim 20 \mathrm{mg} / \mathrm{L}$, therefore when the amount of dissolved oxygen in the water was sufficient, the nitrite could be converted quickly and the harm to the fish schools could be reduced, as shown in Figure $8 \mathrm{~b}$. The nitrite content in the water with an aquaponics system was less than $10 \mathrm{mg} / \mathrm{L}$ in the late stage, therefore the conditions for growth were good.

$\mathrm{NH}_{3}-\mathrm{N}$ comes mainly from the decomposition of animal excrement, residual feed and dead animals and plants. Amino acid is formed during the first stage of decomposition, and then $\mathrm{NH}_{3}-\mathrm{N}, \mathrm{NO}_{2}-\mathrm{N}$, and $\mathrm{NO}_{3}-\mathrm{N}$ are gradually formed. The standard for the content of $\mathrm{NH}_{3}-\mathrm{N}$ in the discharge water is lower than $10 \mathrm{mg} / \mathrm{L}$ in Taiwan. The $\mathrm{NH}_{3}-\mathrm{N}$ content of the vegetable and flower groups was lower than $0.5 \mathrm{mg} / \mathrm{L}$ as a result of this system. The control group did not have an aquaponics system and the eutrophication was severe. The eutrophication increased suddenly to $2.75 \mathrm{mg} / \mathrm{L}$ during March to April, indicating there was moderate pollution, due to decomposing organisms in that period, which led to fish being killed in June. As the dead fish decomposed, the $\mathrm{NH}_{3}-\mathrm{N}$ level increased again. $\mathrm{The} \mathrm{NH}_{3}-\mathrm{N}$ of the water body in the control group rose in March, and then decreased to $0 \mathrm{mg} / \mathrm{L}$ after September. Taking 2 April as an example, the $\mathrm{NH}_{3}-\mathrm{N}$ of the flower group was $0.04 \mathrm{mg} / \mathrm{L}$, that of the vegetable group was $0.01 \mathrm{mg} / \mathrm{L}$, that of the control group was $2.75 \mathrm{mg} / \mathrm{L}$; the difference was 68.7 times. In the control group, the death of fish and algae is the main cause of the increase in $\mathrm{NH}_{3}-\mathrm{N}$ (Figure 8c).

$\mathrm{NO}_{3}-\mathrm{N}$ is the final product of nitrification in the nitrogen cycle, so nitrate nitrogen can indicate the degree of pollution in the water body. When the nitrate nitrogen content in rivers, lakes, or reservoirs is too high, it causes algae to multiply easily, which causes eutrophication in the water body. According to Taiwan's tap water standard, it should be lower than $10 \mathrm{mg} / \mathrm{L}$, and the discharge water standard should be lower than $50 \mathrm{mg} / \mathrm{L}$. Taking 2 July as an example, the $\mathrm{NH}_{3}-\mathrm{N}$ of the flower group was $1.7 \mathrm{mg} / \mathrm{L}$, that of the vegetable group was $1.1 \mathrm{mg} / \mathrm{L}$, and that of the control group was $0.03 \mathrm{mg} / \mathrm{L}$, which were all under the tap water standard of less than $10 \mathrm{mg} / \mathrm{L}$ (Figure 8d).

\section{Conclusions}

According to the comparison between the experimental and control groups, the water quality of the groups with the equipment that was installed was relatively stable, and remained within the effluent regulations. The difference in the $\mathrm{pH}$ values of the vegetable and flower groups was slight, whereas the difference of the control group was 1.2 times lower. The average difference in the dissolved oxygen content of the vegetable and flower groups was about $1 \mathrm{mg} / \mathrm{L}$. The mean difference of the control group was $2 \mathrm{mg} / \mathrm{L}$, and the maximum difference was $6.5 \mathrm{mg} / \mathrm{L}$. The $\mathrm{NH}_{3}-\mathrm{N}$ content of the control group was 68 times that of the experimental groups due to the $\mathrm{NH}_{3}-\mathrm{N}$ derived from dead fish and leftover feed in April. In terms of the $\mathrm{NO}_{2}$ content, due to nitrification in July, the $\mathrm{NH}_{3}-\mathrm{N}$ decomposed into $\mathrm{NO}_{2}$, and the $\mathrm{NO}_{2}$ level suddenly increased to $13 \mathrm{mg} / \mathrm{L}$, which was unsuitable for the aquatic organisms, and it was five to six times higher that of the vegetable and flower groups. In terms of the fish growth rate, the water body of the control group changed too much in the early stage; the Oreochromis mossambicus could not bear the water pollution in the mid- and late-stages, and the fish all died. Thus, it could be seen that the use of floating islands with plants contributed to the improvement of the water quality and provided a favorable living environment for the fish. Therefore, it is suggested that vegetables and 
flowers be planted, using the floating island design of this study, and that either pet fish or edible fish be cultured, by using aquaponics. This system can purify water and provide a growing environment for fish schools, so as to achieve sustainable resources, to purify ambient water, to provide food for humans and to mitigate the food crisis. Our study points out that the Aquaponics System does help to improve the water quality, that vegetables or flowers can obtain a good growth rate by using this system, and that green energy can provide power to irrigate automatically and to convert the nutrients in the water into fertilizer. Although the circular farming facility is simple, it provides useful data, and can be a reference for local farmers. It not only saves energy and prevents water pollution, but it also provides a new option of arable land for the people.

Author Contributions: Conceptualization, C.-C.H., H.-L.L., Y.-H.C., T.-H.H.; methodology, C.-C.H., H.-L.L., Y.-H.C., T.-H.H.; software, C.-C.H., H.-L.L., Y.-H.C., T.-H.H.; validation, C.-C.H., H.-L.L., Y.-H.C., T.-H.H.; formal analysis, C.-C.H., H.-L.L., Y.-H.C., T.-H.H.; investigation, C.-C.H., H.-L.L., Y.-H.C., T.-H.H.; resources, C.-C.H., H.-L.L., Y.-H.C., T.-H.H.; data curation, C.-C.H., H.-L.L., Y.-H.C., T.-H.H.; writing-original draft preparation, C.-C.H., H.-L.L., Y.-H.C., T.-H.H.; writing-review and editing, C.-C.H., H.-L.L., Y.-H.C., T.-H.H.; visualization, C.-C.H., H.-L.L., Y.-H.C., T.-H.H.; supervision, C.-C.H., H.-L.L., Y.-H.C., T.-H.H.; project administration, C.-C.H., H.-L.L., Y.-H.C., T.-H.H.; funding acquisition, C.-C.H., H.-L.L., Y.-H.C., T.-H.H. All authors have read and agreed to the published version of the manuscript.

Funding: This research was funded by Ministry of Science and Technology, Taiwan (MOST 104-2221E-451-012).

Institutional Review Board Statement: Not applicable for studies not involving humans.

Informed Consent Statement: Not applicable for studies not involving humans.

Data Availability Statement: Not applicable.

Acknowledgments: This work was supported by the Ministry of Science and Technology, Taiwan (MOST 104-2221-E-451-012).

Conflicts of Interest: The funders had no role in the design of the study; in the collection, analyses, or interpretation of data; in the writing of the manuscript, or in the decision to publish the results.

\section{References}

1. Council of Agriculture of the Executive Yuan. Agricultural Indicators; Council of Agriculture of the Executive Yuan: Taipei City, Taiwan, 2021. Available online: https://agrstat.coa.gov.tw/sdweb/public/indicator/Indicator.aspx (accessed on 20 February 2021).

2. Roosta, H.R.; Hamidpour, M. Effects of foliar application of some macro- and micro-nutrients on tomato plants in aquaponic and hydroponic systems. Sci. Hortic. 2011, 129, 396-402. [CrossRef]

3. Nicoletto, C.; Maucieri, C.; Mathis, A.; Schmautz, Z.; Komives, T.; Sambo, P.; Junge, R. Extension of aquaponic water use for NFT baby-leaf production: Mizuna and rocket salad. Agronomy 2018, 8, 75. [CrossRef]

4. Maucieri, C.; Nicoletto, C.; Zanin, G.; Birolo, M.; Xiccato, G.; Sambo, P.; Borin, M. Nitrogen budget in recirculating aquaponic systems with different fish stocking density. Ital. J. Agron. 2020, 15, 1639.

5. Tyson, R.V.; Treadwell, D.D.; Simonne, E.H. Opportunities and Challenges to Sustainability in Aquaponic Systems. Horttechnology 2011, 21, 6-13. [CrossRef]

6. Hu, Z.; Lee, J.W.; Chandran, K.; Kim, S.; Khanal, S.K. Nitrous Oxide $\left(\mathrm{N}_{2} \mathrm{O}\right)$ Emission from Aquaculture: A Review. Environ. Sci. Technol. 2012, 46, 6470-6480. [CrossRef]

7. Liang, J.Y.; Chien, Y.H. Effects of feeding frequency and photoperiod on water quality and crop production in a tilapia-water spinach raft aquaponics system. Int. Biodeterior. Biodegrad. 2013, 85, 693-700. [CrossRef]

8. Endut, A.; Jusoh, A.; Ali, N.; Nik, W.B.W.; Hassan, A. A study on the optimal hydraulic loading rate and plant ratios in recirculation aquaponic system. Bioresour. Technol. 2010, 101, 1511-1517. [CrossRef]

9. Hamlin, H.J.; Michaels, J.T.; Beaulaton, C.M.; Graham, W.F.; Dutt, W.; Steinbach, P.; Losordo, T.M.; Schrader, K.K.; Main, K.L. Comparing denitrification rates and carbon sources in commercial scale upflow denitrification biological filters in aquaculture. Aquac. Eng. 2008, 38, 79-92. [CrossRef]

10. Lam, S.S.; Ma, N.L.; Jusoh, A.; Ambak, M.A. Biological nutrient removal by recirculating aquaponic system: Optimization of the dimension ratio between the hydroponic \& rearing tank components. Int. Biodeterior. Biodegrad. 2015, 102, 107-115. [CrossRef] 
11. Martins, C.I.M.; Eding, E.H.; Verdegem, M.C.J.; Heinsbroek, L.T.N.; Schneider, O.; Blancheton, J.P.; d'Orbcastel, E.R.; Verreth, J.A.J. New developments in recirculating aquaculture systems in Europe: A perspective on environmental sustainability. Aquac. Eng. 2010, 43, 83-93. [CrossRef]

12. Environmental Protection Bureau of Yi-Lan County. Yilan County 94 Year Plan to Promote River Patrol Volunteers; Environmental Protection Bureau of Yi-Lan County: Yilan City, Taiwan, 2005.

13. Buzby, K.M.; Lin, L.S. Scaling aquaponic systems: Balancing plant uptake with fish output. Aquac. Eng. 2014, 63, 39-44. [CrossRef]

14. Environmental Protection Administration, R.O.C. Water Quality Monitoring Project and Its Significance. 2013. Available online: http:/ / wqp.epa.gov.tw/ecological/ClassRoom.aspx?Num=01 (accessed on 26 February 2021).

15. FAO. The State of World Fisheries and Aquaculture (SOFIA); Food and Agriculture Organization of the United Nations: Rome, Italy, 2012.

16. Lam, S.S.; Ma, N.L.; Jusoh, A.; Ambak, M.A. A study on the optimal tank design and feed type to the growth of marble goby (Oxyeleotris marmorata Bleeker) and reduction of waste in a recirculating aquaponic system. Desalination Water Treat. 2014, 52, 1044-1053. [CrossRef]

17. Ahn, J.H.; Kim, S.; Park, H.; Rahm, B.; Pagilla, K.; Chandran, K. N $2 \mathrm{O}$ emissions from activated sludge processes, 2008-2009: Results of a national monitoring survey in the United States. Environ. Sci. Technol. 2010, 44, 4505-4511. [CrossRef] [PubMed]

18. Lennard, W.A.; Leonard, B.V. A Comparison of Three Different Hydroponic Sub-systems (gravel bed, floating and nutrient film technique) in an Aquaponic Test System. Aquac. Int. 2006, 14, 539-550. [CrossRef]

19. Sace, C.; Fitzsimmons, K. Vegetable production in a recirculating aquaponics using Nile tilapia (Oreochromis niloticus) with and without freshwater prawn (Macrobrachium rosenbergii). Acad. J. Agric. Res. 2013, 1, 236-250.

20. Hu, Z.; Lee, J.W.; Chandran, K.; Kim, S.; Brotto, A.C.; Khanal, S.K. Effect of plant species on nitrogen recovery in aquaponics. Bioresour. Technol. 2015, 188, 92-98. [CrossRef]

21. Valente, L.M.P.; Linares, F.; Villanueva, J.L.R.; Silva, J.M.G.; Espe, M.; Escorcio, C.; Pires, M.A.; Saavedra, M.J.; Borges, P.; Peleteiro, J.B.; et al. Dietary protein source or energy levels have no major impact on growth performance, nutrient utilisation or flesh fatty acids composition of market-sized Senegalese sole. Aquaculture 2011, 318, 128-137. [CrossRef]

22. Hargreaves, J.A. Nitrogen biogeochemistry of aquaculture ponds. Aquaculture 1998, 166, 181-212. [CrossRef]

23. Hsi Liu Environmental Greening Foundation. Introduction of Artificial Floating Island on Drunken Moon Lake in Taiwan University. 2009. Available online: http:/ /www.hsiliu.org.tw/ (accessed on 26 February 2021).

24. Chang, N.B.; Islam, K.; Marimon, Z.; Wanielista, M.P. Assessing biological and chemical signatures related to nutrient removal by floating islands in stormwater mesocosms. Chemosphere 2012, 88, 736-743. [CrossRef]

25. Wen, L.; Recknagel, F. In situ removal of dissolved phosphorus in irrigation drainage water by planted floats: Preliminary results from growth chamber experiment. Agric. Ecosyst. Environ. 2002, 90, 9-15. [CrossRef]

26. Zhao, F.L.; Xi, S.; Yang, X.E.; Yang, W.D.; Li, J.J.; Gu, B.H.; He, Z.L. Purifying eutrophic river waters with integrated floating island systems. Ecol. Eng. 2012, 40, 53-60. [CrossRef]

27. Fager, L.F.; York, J.C. Floating Islands for Waterfowl in Arizona. Soil Conserv. 1975, 41, 4-5.

28. Hiraoka, T. Utilization of Artificial Floating Objects as Nest Platforms by Little Grebes and Eurasian Coots in Lake Teganuma, Central Japan. J. Yamashina Inst. Ornithol. 1996, 28, 108-112. [CrossRef]

29. Bousselot, J.M.; Klett, J.E.; Koski, R.D. Moisture Content of Extensive Green Roof Substrate and Growth Response of 15 Temperate Plant Species during Dry Down. Hortscience 2011, 46, 518-522. [CrossRef]

30. Monterusso, M.A.; Rowe, D.B.; Rugh, C.L. Establishment and persistence of Sedum spp. and native taxa for green roof applications. Hortscience 2005, 40, 391-396. [CrossRef]

31. Rowe, D.; Monterusso, M.; Rugh, C. Assessment of Heat-expanded Slate and Fertility Requirements in Green Roof Substrates. Horttechnology 2006, 16, 471-477. [CrossRef] 